\section{Proterozoic prism arrests suspect terranes: Insights into the ancient Cordilleran margin from seismic reflection data: Comment and Reply}

\section{Comment}

Derek J. Thorkelson, Department of Earth Sciences, Simon Fraser University, Burnaby, British Columbia V5A 1S6, Canada

J. Grant Abbott, Geological and Exploration Services Division, Indian and Northern Affairs Canada, Whitehorse, Yukon Y1A 2B4, Canada

Charles F. Roots, Geological Survey of Canada, Yukon Geology Program, Box 2703 (K-10), Whitehorse, Yukon Y1A 2C6, Canada

Snyder et al. (2002), in their interpretation of Lithoprobe seismic data, suggested that Proterozoic rocks of the northern Canadian Cordillera occurred in "a long-lived, slowly subsiding rift" and consisted of successions similar to the Modern Indus Fan. With this depiction, the authors have mischaracterized a Proterozoic orogen, spanning more than a quarter of earth history, as a clastic prism. Although the authors acknowledged four major sediment pulses, they ignored the largely platformal environment of sedimentation, and intervening events of deformation, metamorphism, uplift, erosion, magmatism, hydrothermal brecciation, and metallogenesis (Eisbacher, 1978; Thorkelson et al., 2001). The inability of the seismic imagery to reveal these complexities calls into question the interpreted thickness and extent of the Proterozoic rocks relative to their crystalline basement.

Proterozoic supracrustal evolution of the northern Cordillera is understood from extensive Precambrian inliers located mainly north of the transect lines. Deposition began with two clasticcarbonate grand cycles prior to $1.71 \mathrm{Ga}$. By 1.6 Ga these strata had been deformed, metamorphosed, uplifted, and eroded. After mafic magmatism, subsidence, and largely platformal sedimentation at $1.38 \mathrm{Ga}$, the geological environment resembled that of present-day eastern North America, where subsided parts of the Appalachian orogen are overlain by Atlantic passive margin strata. Subsequent events include: mantle-plume magmatism at $1.27 \mathrm{Ga}$; uplift and tilting prior to $\sim 1 \mathrm{Ga}$; platformal sedimentation at $\sim 1 \mathrm{Ga}$; uplift, folding and thrust faulting prior to $0.78 \mathrm{Ga}$; mafic magmatism, rifting, glaciations and platform-to-basin sedimentation from 0.78 to $0.6 \mathrm{Ga}$, and additional uplift and deformation before Cambrian time. Terranes which accreted to ancestral North America in the Mesozoic encountered a mature Proterozoic orogenic belt, not a clastic prism.

\section{REFERENCES CITED}

Eisbacher, G.H., 1978, Two major Proterozoic unconformities, Northern Cordillera, in Current Research, Part A: Geological Survey of Canada, Paper 78-1A, p. 53-58.

Snyder, D.B., Clowes, R.M., Cook, F.A., Erdmer, P., Evenchick, C.A., van der Velden, A.J., and Hall, K.W., 2002, Proterozoic prism arrests suspect terranes: Insights into the ancient Cordilleran margin from seismic reflection data: GSA Today, v. 12, no. 10, p. 4-10.

Thorkelson, D.J., Mortensen, J.K., Davidson, G.J., Creaser, R.A., Perez, W., and Abbott, J.G., 2001, Early Proterozoic magmatism in Yukon, Canada: Constraints on the evolution of northwestern Laurentia: Canadian Journal of Earth Sciences, v. 38, p. 1479-1494.
Reply

D.B. Snyder, Geological Survey of Canada, 615 Booth Street, Ottawa, Ontario K1A OE9, Canada, dsnyder@NRCan.gC.ca

R.M. Clowes, LITHOPROBE and Department of Earth \& Ocean Sciences, University of British Columbia, Vancouver, British Columbia V6T 1Z4, Canada

F.A. Cook, Department of Geology \& Geophysics, University of Calgary, Calgary, Alberta T2N 1N4, Canada

P. Erdmer, Department of Earth \& Atmospheric Sciences, University of Alberta, Edmonton, Alberta T6C 2E3, Canada

C.A. Evenchick, Geological Survey of Canada, 101-605 Robson Street, Vancouver, British Columbia V6B 5J3, Canada

A.J. van der Velden and $\boldsymbol{K}$.W. Hall, Department of Geology \& Geophysics, University of Calgary, Calgary, Alberta T2N 1N4, Canada

Thorkelson et al.'s perceived differences between a Proterozoic orogen and a composite clastic prism are largely perspective and emphasis. The "extensive Precambrian inliers located mainly north of the transect lines" are dominantly supracrustal sedimentary strata with some interlayered volcanics. These supracrustal rocks exceed $20 \mathrm{~km}$ thickness with no "basement" yet recognized. Thorkelson et al. (2001, Fig. 8) noted only the Racklan Orogeny affected this area between 1800 and 1300 $\mathrm{Ma}$ and attributed it to far-field stresses from convergent margins in SW United States or Australia. Eisbacher (1978) describes two erosional unconformities related to local basins. Plume magmatism and related uplift generally characterize rifting events. Geological history is increasingly recognized as primarily passive subsidence punctuated by widely spaced and relatively short orogeny (Dalziel and Soper, 2001).

We take particular issue with the claim that the seismic images are unable to reveal complexities of deformation, uplift, or erosion in the Proterozoic record. The SNORCLE data provide outstanding images of structural and stratigraphic complexities. For example, along line 2 and $\sim 50 \mathrm{~km}$ west of the Tintina fault zone, layering is deformed into a large ( $10 \mathrm{~km}$ amplitude) syncline that is not manifested in the surface rocks (Figure 2 of Snyder et al., 2002). In some cases, such structures are truncated at the base of the Paleozoic strata and probable equivalents to some of the Proterozoic structures referred to by Thorkelson et al. Indeed, the seismic data reveal such complexities that are not only consistent with the limited outcrop information, but that also extend that information over distances and depths previously not possible.

The terranes which accreted to ancestral western North America did encounter a "mature Proterozoic orogenic belt," but this belt originated largely as supracrustal (dominantly clastic) strata deposited in several major pulses with the layers horizontally shortened around the time of deposition as well as later.

\section{REFERENCES CITED}

Dalziel, I.W.D., and Soper, N.J., 2001, Neoproterozoic extension on the Scottish promontory of Laurentia; paleogeographic and tectonic implications: Journal of Geology, v. 109, p. 299-317.

Eisbacher, G.H., 1978, Two major Proterozoic unconformities, Northern Cordillera, in Current Research, Part A: Geological Survey of Canada, Paper 78-1A, p. 53-58.

Snyder, D.B., Clowes, R.M., Cook, F.A., Erdmer, P., Evenchick, C.A., van der Velden, A.J., and Hall, K.W., 2002, Proterozoic prism arrests suspect terranes: Insights into the ancient Cordilleran margin from seismic reflection data: GSA Today, v. 12, no. 10, p. 4-10.

Thorkelson, D.J., Mortensen, J.K., Davidson, G.J., Creaser, R.A., Perez, W., and Abbott, J.G., 2001, Early Proterozoic magmatism in Yukon, Canada: Constraints on the evolution of northwestern Laurentia: Canadian Journal of Earth Sciences, v. 38, p. 1479-1494. 